Pesq. Vet. Bras. 28(5):241-248, maio 2008

\title{
The number and profile of reactive NADH-d and NADPH-d neurons of myenteric plexus of six-month-old rats are different in the cecum portions ${ }^{1}$
}

\author{
Elizangela A. Silva ${ }^{2 *}$, Maria R.M. Natali ${ }^{3}$ and Isaura M.M. Prado ${ }^{3}$
}

\begin{abstract}
Silva E.A., Natali M.R.M. \& Prado I.M.M. 2008. The number and profile of reactive NADH-d and NADPH-d neurons of myenteric plexus of six-month-old rats are different in the cecum portions. Pesquisa Veterinária Brasileira 28(5):241248. Departamento de Cirurgia, Faculdade de Medicina Veterinária e Zootecnia, USP, Cidade Universitária, Av. Prof. Dr. Orlando Marques de Paiva 87, São Paulo, SP 05508270. E-mail: elizangela@usp.br

Whole-mount preparations were prepared and submitted to NADH-diaphorase and NADPH-diaphorase histochemistry techniques. The myenteric plexus arrangement and the number of neurons were comparatively evaluated among the different portions of the cecum. The neurons from the apical and basal regions were distributed in classes at intervals of $100 \mu \mathrm{m}^{2}$, the means of the corresponding intervals being compared. The ganglia, in both techniques, were often connected by fine bundles, which became thicker in the mesenteric region and in the region next to the cecal ampulla. The number of positive NADH-d neurons was higher than that of NADPH-d neurons in all portions, from both regions. The numbers of reactive NADH-d e NADPH-d neurons were significantly different among the different portions of the cecum, except for the antimesenteric basal and intermediate basal regions, considering the NADH-d neurons. The profile area for the reactive NADH-d e NADPH-d neurons was higher in the apical region than in the basal area. Differences in arrangement, distribution and size of positive NADH-d e NADPH$\mathrm{d}$ neurons in the different cecum portions evidenced the importance of the subdivision of the analyzed organ.
\end{abstract}

INDEX TERMS: Myenteric neurons, cecum portions, cecum, Wistar rats.

${ }^{1}$ Received on November 30, 2007.

Accepted for publication on April 10, 2008.

Part of the Master Dissertation "Morphological and quantitative evaluation of the neurons from myenteric plexus in different cecum portions of six- and twelve-month-old rats, sedentary, and submitted to regular physical activity with twelve months", presented to the Faculty of Veterinary Medicine and Animal Science, USP, São Paulo.

Financial Support: Coordenadoria de Aperfeiçoamento de Pessoal de Nível Superior (CAPES).

${ }^{2}$ Setor Anatomia dos Animais Domésticos e Silvestres, Departamento de Cirurgia, Faculdade de Medicina Veterinária e Zootecnia, Universidade de São Paulo (USP), Av. Prof. Dr. Orlando Marques de Paiva 87, Cidade Universitária, São Paulo, SP 05508-270, Brazil. *Corresponding author: elizangela@usp.br

${ }^{3}$ Departamento de Ciências Morfofisiológicas (CCB/DCM), Universidade Estadual de Maringá, Av. Colombo 5790, Zona 7, Maringá, PR 87020-900, Brazil.
RESUMO.- [O número de neurônios e a área do perfil neuronal NADH-d e NADPH-d reativos do plexo mioentérico de ratos com seis meses de idade são diferentes nas diferentes porções e regiões do ceco.] Estudaram-se o arranjo do plexo mioentérico, o número de neurônios e a área do perfil do corpo celular $\left(\mu \mathrm{m}^{2}\right)$ dos neurônios mioentéricos, nas regiões apical e basal do ceco de ratos Wistar com 6 meses de idade. Estas regiões foram subdivididas nas seguintes porções: apical mesentérica (AM); apical intermediária (Al); apical antimesentérica $(\mathrm{AA})$; próximo à ampola cecal $(\mathrm{PA})$; basal intermediária (BI), e basal antimesentérica (BA). Foram montados preparados de membrana que receberam as técnicas histoquímica de NADH-diaforase (NADH-d) e NADPHdiaforase (NADPH-d). O arranjo do plexo mioentérico e o número de neurônios foram avaliados comparativamente 
entre as diferentes porções das regiões do ceco. Os neurônios das regiões apical e basal foram distribuídos em classes com intervalos de $100 \mu \mathrm{m}^{2}$, sendo comparadas às médias da mensuração dos pares. Os gânglios, em ambas as técnicas, apresentavam-se, em geral, conectados por feixes delicados, tornando-se mais espessos na porção mesentérica e naquela próxima à ampola cecal. O número de neurônios NADH-d positivos foi maior do que o de NADPH-d em todas as porções, de ambas as regiões. O número de neurônios reativos a NADH-d e NADPH-d foi significativamente diferente entre as diferentes porções do ceco, com exceção das comparações entre as porções basal antimesentérica e basal intermediária, para os primeiros; e entre a basal intermediária e porção próxima à ampola cecal, e comparando-se a apical mesentérica e porção próxima à ampola cecal, para os neurônios NADPH-d positivos. A área do perfil dos neurônios NADH-d e NADPH-d reativos foi maior na região apical do que na basal. Pela primeira vez, o número de neurônios do plexo mioentérico é reportado em porções pré-estabelecidas do ceco de ratos. Nossos resultados reiteram a importância da indicação precisa da porção estudada em pesquisas envolvendo este segmento intestinal.

TERMOS DE INDEXAÇÃO: Neurônios mioentéricos, porções cecais, ceco, ratos Wistar.

\section{INTRODUCTION}

The cecum, the first segment of the large intestine, with specific microbiota, contributes to the maintenance of homeostasis. In herbivorous, its microflora allows fermentation of the alimentary bolus from the small intestine, which is necessary for cellulose digestion (Bruns et al. 1977, Rerat 1978). In rodents, it is involved in cellulose breaking and in partial absorption of the digestion products (Rerat 1978). This segment has been indicated as responsible for the absorption of important nutrients, such as: calcium (Petith \& Schedl 1976); vitamin K (Hollander \& Truscott 1974); magnesium (Rayssiguier \& Remesy 1977), in addition to water and electrolytes (Donowitz \& Binder 1979) and in the use of volatile fatty acids as well (Bond \& Levitt 1976). Moreover, $20 \%$ of the carbohydrate and proteins not digested in the small intestine may be digested by the cecum microflora (Rerat 1978).

The cecum motor activity is commanded, as the whole large intestine, by particular extrinsic and intrinsic mechanisms of neural control. The intrinsic control is responsible, ultimately, for several functions of the gastrointestinal tract (GIT), such as secretion, water and electrolytes transport, intestinal blood flow (Sternini 1988), motility (Hansen 2003) and also acts in the intestinal immune system. The myenteric plexus is one of the intrinsic components of the Enteric Nervous System (ENS) and it is not equally distributed in the GIT. In fact, it shows a different distribution in the distinct segments and even within a single intestinal segment.
The particular conformation and activity of the cecum determine a distinct motor activity of its different regions (Roger et al. 1991), therefore a specific neuronal control is suspected. Research on the morphofunctional characteristics of the cecum, in several animals, has paid attention to the intrinsic innervation. The rat is, by excellence, the main experimental model for functional studies, so the morphology and density of the myenteric neurons of this segment have been widely investigated in this species (Dupont et al. 1965, Gabella 1971, Barbosa 1973, Bruns et al. 1977, Snipes 1981, Roger et al. 1991, Young et al. 1992, Fregonesi et al. 1998, Oliveira et al. 2002, Seyfert 2003). However, few authors have been concerned with the distribution of these neurons in the different cecum portions (Dupont et al. 1965, Seyfert 2003).

In the present study, we intend to evaluate the number and cell profile area of the positive NADH-diaphorase and $\mathrm{NADPH}$-diaphorase myenteric neurons from the cecum of six-month-old Wistar rats, in pre-established portions of the apical and basal regions of this intestinal segment.

\section{MATERIALS AND METHODS}

\section{Animal treatment}

Ten 6-month-old male Wistar rats were used. This research was conducted under the guidelines established by the Bioethics Committee of the Faculty of Veterinary Medicine and Animal Science of the University of São Paulo, São Paulo, Brazil. The animals were weighted $(439.5 \pm 13.1 \mathrm{~g})$ and anesthetized with intraperitoneal tiopental, and a laparotomy was performed in order to remove the cecum (cranial limit - ileocecal junction; caudal limit - cecal-colic junction). After that, the intestinal segments were washed with saline solution and prepared for the different techniques. The ceca of five animals were submitted to the positive NADH-diaphorase (NADH-d) histochemistry technique and the other five were submitted to the positive NADPH-diaphorase (NADPH-d).

\section{Tissue preparation}

The ceca were washed with Krebs solution $(\mathrm{pH} 7.3)(1,3 \mathrm{~g}$ of $\mathrm{NaHCO}_{3} ; 0,24 \mathrm{~g}$ of $\mathrm{MgCl}_{2} \cdot 6 \mathrm{H}_{2} \mathrm{O} ; 0,44 \mathrm{~g}$ of $\mathrm{KCl} ; 0,165 \mathrm{~g}$ of $\mathrm{NaH}_{2} \mathrm{PO}_{2} ; 7,05 \mathrm{~g}$ of $\mathrm{NaCl} ; 0,27 \mathrm{~g}$ of $\mathrm{CaCl}_{2}$, in a liter of distillated water); then had one of the ends (the ileocecal junction ) tied with a cotton thread, were filled with the same solution using a syringe, and had the opposite end (cecal-colic junction) tied, forming in this way a fluid-filled vesicle. After that, this material was washed twice in Krebs solution (10 minutes each), and was made permeable by adding Triton $\mathrm{X}-100$ (0.3\%) dissolved in sodium phosphate buffer (PBS), $\mathrm{pH} 7.3$, where it remained for a variable time according to the technique used.

\section{NADH histochemistry}

In the NADH-diaphorase technique (Gabella 1969), the cecum segments remained in the permeabilizing solution for five minutes. After that, the segments were washed twice (10 minutes each) in Krebs solution, and incubated in the following reaction medium: $25 \mathrm{~mL}$ of storage solution of Nitro Blue Tetrazolium (NBT - Synth ${ }^{\circledR}$, Diadema, São Paulo, Brasil, storage solution at the concentration of $0.5 \mathrm{mg} / \mathrm{mL}$ ); $25 \mathrm{~mL}$ of sodium phosphate buffer $(0.1 \mathrm{M})$, $\mathrm{pH} 7.3 ; 50 \mathrm{~mL}$ of distilled water and $0.05 \mathrm{~g}$ of $\beta-\mathrm{NADH}\left(\mathrm{Synth}^{\circledR}\right)$. The development of the reaction 
was visually controlled under a stereomicroscope (Tecnival ${ }^{\circledR}$, Carl Zeiss, Jena, Germany). The incubation lasted, on average, for 45 minutes. After that, the cecum segments were longitudinally opened along their longitudinal axis and fixed in $10 \%$ formaldehyde, sodium phosphate buffer $(0.1 \mathrm{M}), \mathrm{pH} 7.3$, until the dissection was performed.

\section{NADPH histochemistry}

For the NADPH-diaphorase technique performance (Scherer-Singler et al. 1983), five cecum segments were made permeable for 10 minutes. After that, they were washed twice (10 minutes each) in sodium phosphate buffer (PBS), then incubated in the reaction medium constituted of Nitro Blue Tetrazolium (NBT, Synth $\left.{ }^{\circledR}\right)(0.25 \mathrm{mg} / \mathrm{mL}) ; \beta-\mathrm{NADPH}$ (Synth) $(0.5 \mathrm{mg} / \mathrm{mL})$, and Triton X-100 $\left(\right.$ Synth $\left.^{\circledR}\right) 0.3 \%$, in Tris-HCl buffer $\left(\right.$ Synth $\left.^{\circledR}\right)(0.1 \mathrm{M}), \mathrm{pH}$ 7.6. The development of the reaction was visually controlled with the aid of a stereomicroscope (Tecnival ${ }^{\circledR}$ ), and lasted about two hours. The cecum segments were opened and immersed in $4 \%$ formaldehyde solution, in order to be fixed and stored.

\section{Obtention of whole-mount preparations}

Whole-mount preparations were prepared in order to expose the myenteric plexus, placed between the longitudinal and circular muscular layers. After fixation, the microdissection was performed under a stereomicroscope (Tecnival ${ }^{\circledR}$ ) with transillumination (increase: $4 \mathrm{X}$ ) using appropriate clamps and scissors. The mucosal and the submucosal layers were removed, care being taken to preserve the muscular tunics and the myenteric plexus. The whole-mount preparations were placed on the slide; received glycerin in sodium phosphate buffer $\left(\right.$ Synth $\left.^{\circledR}\right)$, and were covered with cover glasses, the sealing being completed with enamel.

\section{Quantification of neuron numbers}

For the quantitative analysis, the cecum ventral face (Fig.1a) was divided in apical and basal regions (Fig.1b), and each one of them was further subdivided into three portions (Fig.1c), based on Seyfert (2003): mesenteric apical (MA); intermediate apical (IA); antimesenteric apical (AA); next to the cecal ampulla (NCA); intermediate basal (IB), and antimesenteric basal (AB). In each portion, 40 microscopic fields were counted, using an Olympus BX-40 F4 microscope, with objective lens of $40 x$ and ocular lens of $10 x$, totaling 240 fields in both regions. The area of each

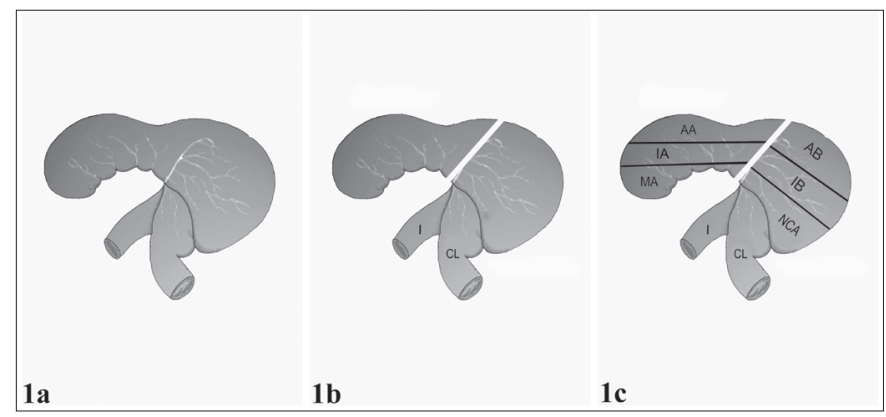

Fig.1. Schematic drawing of cecum, ileum (I) and colon (CL), in its ventral face (1a), indicating the different regions and portions; (1b) Apical and basal regions; (1c) Cecum portions: MA (mesenteric apical); IA (intermediate apical); AA (antimesenteric apical); NCA (next to the cecal ampulla); IB (intermediate basal), and AB (antimesenteric basal). microscopic field was $0.424 \mathrm{~mm}^{2}$, yielding $16.98 \mathrm{~mm}^{2}$ in the 40 studied fields. The reactive neurons were counted in 40 fields per portion, obeying a proportion of 1:3 fields, that is, one field was counted and the next three were ignored. All neurons on the field were counted, half-seen neurons being counted randomly (half-seen neurons were counted in one field and not in the next). In the right upper side of each figure of a neuronal image we present a schematic drawing indicating the portion studied.

\section{Morphometric analysis}

The capture of neuronal images for further measurements was done using an Olympus U-KPA microscope, model BX50F3 (objective lens of $40 x$ and ocular lens of 10x), coupled to a Pro-series 3CCD digital camera and the Image Pro Plus V.4.5.1 program (Media Cybernetics). Each captured field corresponded to $10.913 \mu \mathrm{m}^{2}$. The images were randomly captured from the antimesenteric to the mesenteric portion, following the path of a single ganglion, until 35 neurons in each portion had their images captured, totaling 105 neurons per region. The images were saved in CD-Rom for further analysis. The same program (Image Pro Plus V.4.5.1, Media Cybernetics), installed in a computer (Pentium ${ }^{\circledR}$ IV 2.6, 512MB, HD 80GB), was used to measure the neuronal area. The areas of 100 neurons of each region were measured, considering the three portions, making a total of 200 cell bodies per cecum. The neurons were grouped in intervals of neuronal area of $100 \mu \mathrm{m}^{2}$ each (Gabella 1971, Barbosa 1973).

\section{Statistical analysis}

In order to analyze the obtained results we performed the following statistical tests: 1 . Student's t test, considering the variables (apical $x$ basal region), to compare the neuronal measurement and 2. Nonparametric analysis of variance with Friedman's test, to compare the total number of reactive neurons in the studied fields, of the apical and basal regions (apical total $x$ basal total) and multiple comparisons (two by two) between the different portions of the apical (AA x IA; IA x MA; AA x MA) and basal regions ( $A B \times I B ; A B \times N C A$; IB $\times$ NCA), which can be considered statistically different. For this study the statistical program STATISTICA (Stat Soft, Inc., Statistica, www.statsoft.com, 2004) 7.0 version, was employed. In both statistical tests 0.05 or $5 \%(\alpha \leq 0.05)$ was considered as the rejection level of the nullity hypothesis.

\section{RESULTS}

\section{Myenteric plexus arrangement}

The positive NADH-d and NADPH-d reactive neurons were placed between the circular and longitudinal layers of the cecal muscular tunica, either isolated or, more frequently, organized in ganglia. Most of the ganglia were elongated, with their longest axis following the direction of the circular layer, and were connected to each other through nerve fibers of different thicknesses (primary bundles, secondary bundles and the tertiary bundles), which in turn were interconnected, forming a nerve net.

In general, the net of NADH-d reactive neurons presented less evident nerve fibers, preventing the identification of a particular arrangement (Fig.2). The ganglia showed large gaps between them and were connected by thin bundles. However, in the mesenteric 

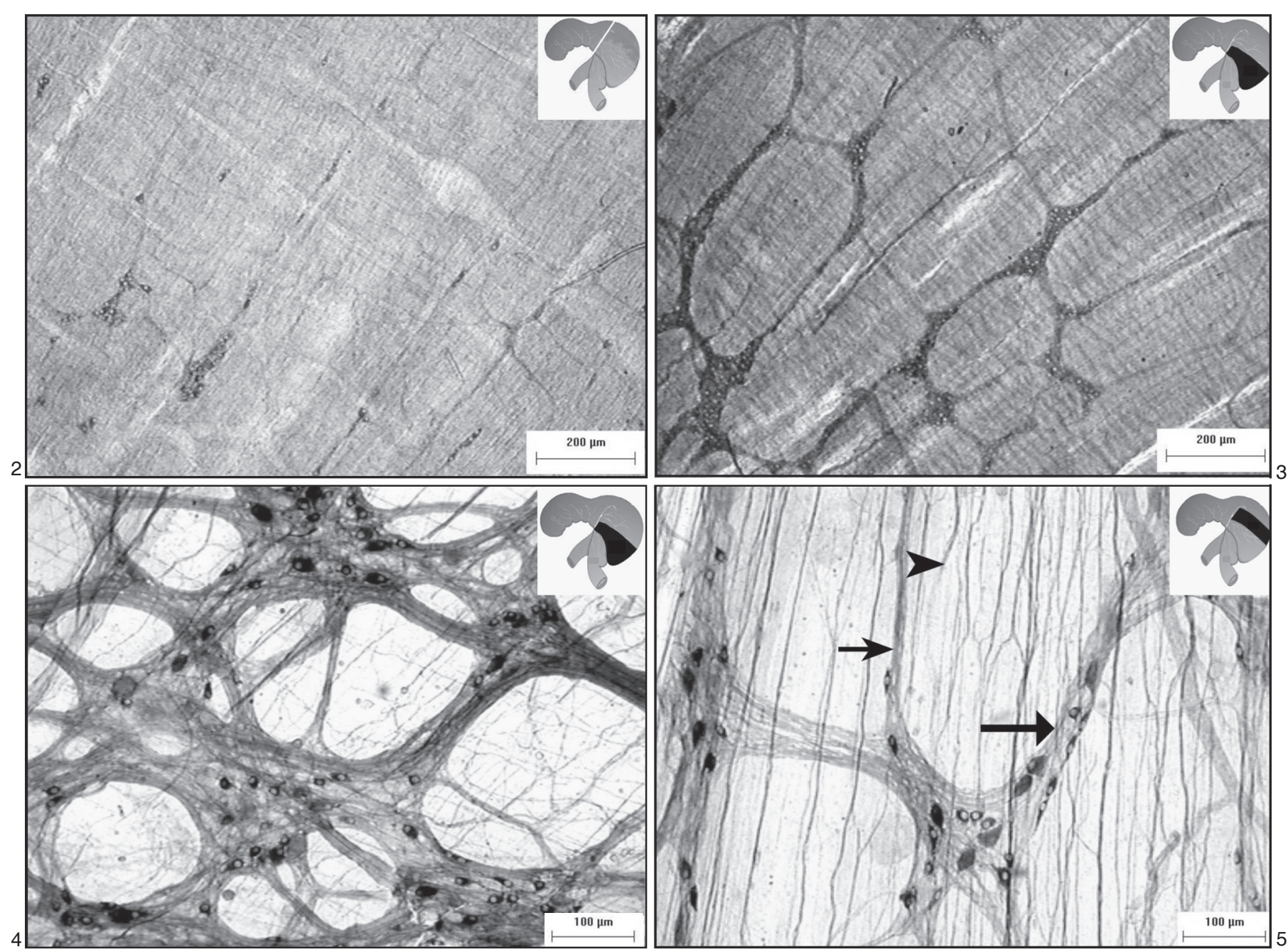

Fig.2. Micrograph of rat cecum, showing the nerve bundles of the myenteric plexus in the antimesenteric portion. Notice that is not possible to distinguish any particular sketch. Technique: NADH-d.

Fig.4. Micrograph of rat cecum. Notiee the thick bundles of nerve fibers in the portion next to the cecal ampulla. Technique: NADPH-d.

portion and next to the cecal ampulla the bundles were thicker, and organized as meshes, predominately oval or rectangular (Fig.3). The NADH-d reactive neurons had different shapes (drop-like, oval, elongated, triangular and rounded) predominately drop-like, with central or peripheral nucleus.

The NADPH-d technique showed thick bundles forming a dense nerve plexus in the mesenteric apical portion and next to the cecal ampulla (Fig.4), and more elongated bundles in the intermediate and antimesenteric portions (Fig.5). The meshes formed by this nerve plexus had several shapes, as pyriform, square, rounded, oval, rectangular, and triangular. In the portions next to the cecal ampulla the ganglia were closer to each other, and the rounded shape of the meshes was predominant. The shape

Fig.3. Micrograph of rat cecum, evidencing the different conformations of the nerve fiber meshes, in the portion next to the cecal ampulla. Technique: NADH-d.

Fig.5. Micrograph of rat cecum, evidencing nerve fiber bundles of different thicknesses - primary (large arrow); secondary (medium arrow) and tertiary (arrowhead), in the intermediate portion of the cecum basal region. Technique: NADPH-d.

and size of the reactive NADPH-d neurons varied. Most presented an elongated shape, with predominantly rounded nucleus placed at the periphery of the cell. Triangular neurons with peripheral nucleus; rounded, drop-like and star-shaped neurons with central nucleus were also identified.

\section{Quantification of neuron numbers}

The number of NADH-d neurons was higher than that of NADPH-d neurons in all portions of both regions, from all studied groups (Tables 1-4). The number of positive $\mathrm{NADH}-\mathrm{d}$ reactive neurons differed in the different portions of the apical and basal regions (Table 1), and it was not significant only between the antimesenteric basal and intermediate basal portion (Table 2). 
Table 1. Six-month-old Wistar rats, according to the number of reactive NADH-d neurons, in $\mathbf{4 0}$ fields per portion, in the different cecum portions. São Paulo, 2006

\begin{tabular}{ccccccc}
\hline $\begin{array}{c}\text { Observation } \\
\text { Number }\end{array}$ & $\mathrm{AA}$ & $\mathrm{IA}$ & $\mathrm{MA}$ & $\mathrm{AB}$ & $\mathrm{IB}$ & $\mathrm{NCA}$ \\
\hline I & 2,150 & 1,972 & 3,764 & 2,747 & 4,522 & 5,089 \\
II & 3,171 & 3,523 & 4,082 & 4,068 & 3,314 & 3,205 \\
III & 1,326 & 1,848 & 2,158 & 2,983 & 3,863 & 3,593 \\
IV & 1,721 & 3,108 & 3,674 & 3,670 & 3,729 & 4,111 \\
V & 2,092 & 2,613 & 3,419 & 3,367 & 3,857 & 3,999 \\
Total & 10,460 & 13,064 & 17,097 & 16,835 & 19,285 & 19,997
\end{tabular}

AA: antimesenteric apical; IA: intermediate apical; MA: mesenteric apical; AB: antimesenteric basal; IB: intermediate basal; NCA: next to cecal ampulla.

Table 2. Comparative analysis considering the NADH-d reactive neurons, among the different cecum regions and portions from six-month-old rats, according to

Friedman's test, $5 \%(\alpha \leq 0.05)$ (the significant values are indicated by “*”'). São Paulo, 2006

\begin{tabular}{|c|c|c|c|c|}
\hline$A A \times I A$ & * & $A B \times I B$ & & $\mathrm{AA} \times \mathrm{AB}$ \\
\hline $\mathrm{AA} \times \mathrm{MA}$ & * & $\mathrm{AB} \times \mathrm{NCA}$ & * & $|A \times| B$ \\
\hline $\mathrm{IA} \times \mathrm{MA}$ & * & $\mathrm{IB} \times \mathrm{NCA}$ & * & $\mathrm{MA} \times \mathrm{NCA}$ \\
\hline
\end{tabular}

AA: antimesenteric apical; IA: intermediate apical; MA: mesenteric apical; AB: antimesenteric basal; IB: intermediate basal; NCA: next to the cecal ampulla.

Table 3. Six-month-old Wistar rats, according to the number of NADPH-d reactive neurons, in $\mathbf{4 0}$ fields per portion in the different cecum portions. São Paulo, 2006

\begin{tabular}{ccccccc}
\hline $\begin{array}{c}\text { Observation } \\
\text { Number }\end{array}$ & $\mathrm{AA}$ & $\mathrm{IA}$ & $\mathrm{MA}$ & $\mathrm{AB}$ & $\mathrm{IB}$ & $\mathrm{NCA}$ \\
\hline I & 176 & 180 & 289 & 218 & 290 & 533 \\
II & 86 & 104 & 134 & 145 & 248 & 298 \\
III & 209 & 197 & 215 & 115 & 158 & 307 \\
IV & 66 & 130 & 107 & 77 & 111 & 320 \\
V & 64 & 109 & 150 & 82 & 124 & 219 \\
Total & 601 & 720 & 895 & 637 & 931 & 1,677
\end{tabular}

AA: antimesenteric apical; IA: intermediate apical; MA: mesenteric apical; AB: antimesenteric basal; IB: intermediate basal; NCA: next to the cecal ampulla.

Table 4. Comparative analysis considering the NAPDH-d reactive neurons, among the different cecum regions and portions from six-month-old rats, according to

Friedman's test, $5 \%(\alpha \leq 0.05)$ (the significant values are indicated by “"*”). São Paulo, 2006

\begin{tabular}{|c|c|c|c|c|}
\hline $\begin{array}{c}A A \times I A \\
A A \times M A \\
I A \times M A\end{array}$ & * & $\begin{array}{c}A B \times I B \\
A B \times N C A \\
I B \times N C A\end{array}$ & $\begin{array}{l}\text { * } \\
\text { * }\end{array}$ & $\begin{array}{c}\mathrm{AA} \times \mathrm{AB} \\
\mathrm{IA} \times \mathrm{IB} \\
\mathrm{MA} \times \mathrm{NCA}\end{array}$ \\
\hline
\end{tabular}

AA: antimesenteric apical; IA: intermediate apical; MA: mesenteric apical; AB: antimesenteric basal; IB: intermediate basal; NCA: next to the cecal ampulla.

The different portions of the apical and basal regions differed concerning the positive NADPH-d reactive neurons
(Table 3). The comparative analysis of the results, considering the cecum portions and regions, is presented in Table 4.

\section{Regional distribution and size of myenteric neurons}

The area $\left(\mu \mathrm{m}^{2}\right)$ of the NADH-d and NADPH-d reactive neurons (cellular body) from the cecum apical and basal regions varied, respectively, from 56.46 to $1,128.95$ and from 152.94 to 2,064.02. According to the values of the neuronal profile area found for the different cecum regions, the NADH-d and NADPH-d reactive neurons were distributed in classes, at intervals of $100 \mu \mathrm{m}^{2}$.

The distribution frequency of the neuronal area varied according to the histochemistry employed and the region studied. Most of the NADH-d reactive neurons, in the apical region, were found from 201 to $500 \mu \mathrm{m}^{2}$, and, in the basal region, from 101 to $400 \mu \mathrm{m}^{2}$ (Fig.6). Most of the positive NADPH-d neurons in the apical region were over $900 \mu \mathrm{m}^{2}$. In the basal region the frequency was higher from 301 to $500 \mu \mathrm{m}^{2}$ (Fig.7). The statistical analysis indicated a larger

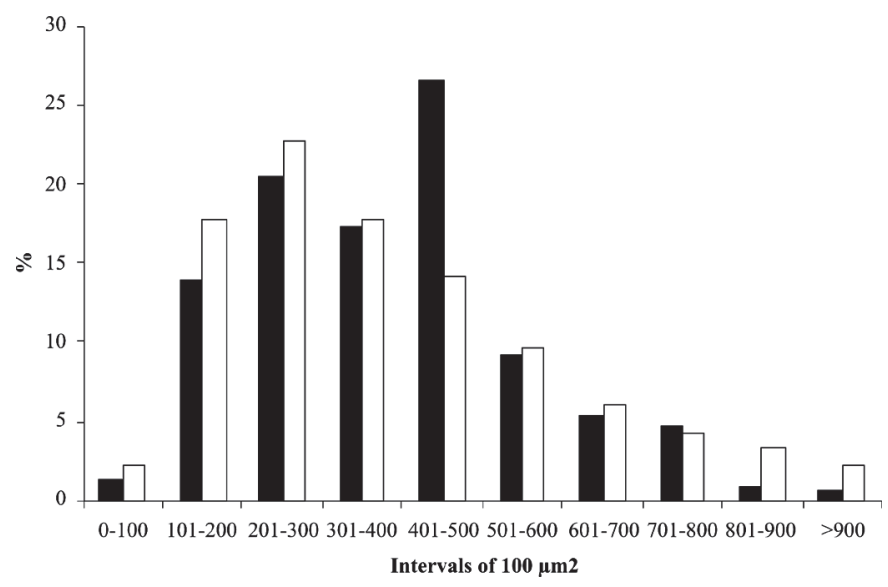

Fig.6. Representative histogram of the distribution frequency of the reactive $\mathrm{NADH}$-diaphorase neurons in apical (ם) and basal $(\square)$ cecum regions in six-month-old Wistar rats, in intervals of $100 \mu \mathrm{m}^{2}$ of area.



$101-200 \quad 201-300 \quad 301-400 \quad 401-500 \quad 501-600 \quad 601-700 \quad 701-800 \quad 801-900 \quad>900$ Intervals of $100 \mu \mathrm{m} 2$

Fig.7. Representative histogram of the distribution frequency of the reactive NAPDH-diaphorase neurons in apical (ם) and basal $(\square)$ cecum regions in six-month-old Wistar rats, in intervals of $100 \mu \mathrm{m}^{2}$ of area. 
profile area of the positive NADH-d and NADPH-d neurons (at a significance level of 0.05 ) in the apical region than in the basal area.

\section{DISCUSSION}

The NADH-d and NADPH-d histochemistry techniques allowed us to evaluate the myenteric plexus from rat cecum according to the arrangement, shape, distribution and area of neuronal profile. Currently, these techniques are being satisfactorily used to evaluate neurons from the myenteric plexus (Gabella 1979, Miranda-Neto et al. 2001). In spite of the NADH-d technique not evidencing all the neurons, it does stain neurons with greater activity of this enzyme (Sant'ana et al. 1997). On the other hand, the histochemistry of the NADPH-d has been largely employed in the last years, because several studies indicate that the neurons it evidences express the enzyme nitric oxide synthase (NOS) (Young et al. 1992, Toole et al. 1998), and thus may use nitric oxide as a neurotransmitter, being relaxation-promoting neurons or inhibitory interneurons of the myenteric plexus (Wilhelm et al. 1998).

The NADH-d and NADPH-d reactive neurons were placed between the circular and longitudinal layers of the cecum muscular tunica, isolated or, more frequently, organized in ganglia, according to what was described in other species and in different segments of the GIT (Gabella 1979, Gershon 1981, Christensen et al. 1984, Costa \& Brookes 1994, Gershon et al. 1994, Wood 1994, Furness \& Bornstein 1995, Goyal \& Hirano 1996, Brookes 2001, Castelucci et al. 2002, Hanani 2004, Schemann \& Neunlist 2004).

The net of NADH-d reactive neurons exhibited less evident nerve bundles, not being possible to identify a particular arrangement in either region. The NADPH-d reactive neurons, on the other hand, had more evident bundles, especially in the mesenteric portion and next to the cecal ampulla. The presence of thick bundles in these portions is justified by their characteristics; in the mesenteric region, the neurons could contribute to the innervation of the smooth muscle fibers of the intestinal wall and the vascular plexus which penetrates it (MirandaNeto et al. 2001) and, in the portion next to the cecal ampulla, the higher number of bundles is a result of the higher thickness of the muscular tunica and a high motor activity attributed to this portion (Dupont et al. 1965, Snipes 1981, Roger et al. 1991, Seyfert 2003).

The great variety of ganglionar shapes of the myenteric plexus, in both techniques used, agreed with what was described for this plexus through different techniques, and in different species (Gabella 1979, Seyfert 2003, Hanani 2004).

The number of NADH-d and NADPH-d reactive neurons differed among the different cecum portions and regions, pointing to the importance of the adequate choice of the portion to be studied in research involving this segment. In fact, few studies about the evaluation of the number of the myenteric neurons in the GIT, particularly in saccular segments, distinguish the regions of material collection (Peng et al. 2001, Molinari et al. 2002, Seyfert 2003). Differences in neuronal density of myenteric plexus from the same intestinal segment were also found in the large intestine of guinea pig (Irwin 1931); rat colon (Barbosa 1973); rat ileum (Miranda-Neto et al. 2001), and human esophagus (De Souza et al. 1988). In guinea pigs, the relative proportion of positive NADPH-d myenteric neurons is higher in the esophagus (54-69\%) (Furness et al. 1994, Morikawa \& Komuro, 1998) than in the stomach $(21 \%)$, small intestine (12-19\%) and colon (25\%) (Furness et al. 1994). The results obtained by Wu et al. (2003) indicate that about $64-89 \%$ of the myenteric neurons in esophagus of young and old rats are positive NADPH-d neurons. This proportion is high when compared to other results found in another parts of gastrointestinal tract: $29-38 \%$ in stomach (Timmermans et al. 1999); 28\% in duodenum (Jarvinen et al. 1999); $15-27 \%$ in ileum (Cracco \& Filogamo 1994, Cowen et al. 2000) and $12-57 \%$ in colon (Nichols et al. 1993).

The statistical analysis indicated significant differences ( $p$ value $<5 \%$ ) in the number of NADPH-d reactive neurons, in animals aging six months, between the different portions of both regions studied, except on the portion next to the cecal ampulla when compared to the mesenteric apical portion (different regions) and the intermediate basal portion (same region) (Table 4). Similar result was obtained for the NADH-d neurons (Table 2). The large variation in the number of neurons distributed on the different cecal portions is related to the presence of a larger amount of nerve fibers from neurons responsible for the innervation of the muscle fibers and the venous plexus penetrating the organ by the mesenteric border and the high motor activity in the basal region of the cecum (Dupont et al. 1965, Snipes 1981, Roger et al. 1991). In our work we observed that the farther from the mesenteric portions and basal region, the smaller the number of neurons.

The profile area of the NADH-d and NADPH-d reactive neurons was higher in the apical area than in the basal area. It is a fact that many ways can be adopted to classify the size of neurons from myenteric plexus (Furlan 2000). In a general way, the neurons are classified as small, medium and large, or, according to the size of profile area, the neurons are distributed in classes at intervals of $100 \mu \mathrm{m}^{2}$, as adopted by us. The classification into small, medium and large, despite being widely used, is relatively "subjective", once there are several adopted parameters Burnstock (1959) categorized as small nerve cells the ones with a diameter of 10-15 $\mu \mathrm{m}$; Gabriel et al. (1988) employed the multiplication of the longitudinal and transversal axis of the neuronal cell body; Fregonesi et al. (1998) determined the neuronal sizes according to the sum of these axis; and finally there is the evaluation of the profiles of the neuronal cell bodies (Gabella 1971).

Though some authors had used the same methodology as ours (Castelucci et al. 2002, Seyfert 2003), the comparison of our results was impaired, once our research 
is very peculiar, not only in what concerns the studied segment (different cecum portions) but also the statistical analysis employed.

Dupont et al. (1965) evaluated the measurement of the reactive NADPH-d myenteric neurons in the $A 1$ and $A$ cecum portions (antimesenteric and mesenteric portions of the basal portion, respectively) from 30 Fisher rats. The cellular size was established by the sum of the two largest perpendicular diameters of each neuron divided by two. It was observed that $67 \%$ were medium neurons (10-20 $)$; "monstrous" neurons (156.1 $\mathrm{\mu})$, as mentioned in the study, were observed in the cecum of the treated animals. Gabella (1971) observed the neuronal average size in the small intestine ranging from 50 to $750 \mu \mathrm{m}^{2}$; and between $75 \mu^{2}$ and $975 \mu \mathrm{m}^{2}$ in the cecum, reaching, in this large intestine segment, $6,500 \mu \mathrm{m}^{2}$, being this the largest neuron found in all segments.

Our results indicate differences in arrangement, distribution and size of positive NADH-d and NADPH-d neurons in the different portions and regions of the rat cecum, stressing the importance of the subdivision of the analyzed organ, and of the identification of the exact place of the collected material in investigation involving this important intestinal segment.

Acknowledgements.- The authors thank Dr. Romeu Rodrigues de Souza, Dr. Naianne Kelly Klebis, Dr. Karina Martinez Gagliardo, and José Antônio de Souza for their superb technical support and Francisco Rodrigues de Camargo Neto for his important illustrative contribution.

\section{REFERENCES}

Barbosa A.J.A. 1973. Auerbach's plexus of the albino rat. I. Quantitative study of the ganglia and nerve cells in the caecum and colon. Braz. J. Med. Biol. Res. 6:253-262.

Bond Jr J.H. \& Levitt M.D. 1976. Fate of soluble carbohydrate in the colon of rats and man. J. Clin. Invest. 57:1158-1164.

Brookes S.J.H. 2001. Classes of enteric nerve cells in the guinea-pig small intestine. Anat. Rec. 262:58-70.

Bruns P., Hood L.F. \& Seeley H.W. 1977. Effects of modified starch on the microflora of the small intestine and caecum of rats. Nutr. Rep. Int. 15:131-138.

Burnstock G. 1959. The innervation of the gut of the brown trout (Salmo trutta). Q. J. Microsc. Sci. 100:199-220.

Castelucci P., De Souza R.R., De Angelis R.C., Furness J.B. \& Liberti E.A. 2002. Effects of pre- and postnatal protein deprivation and postnatal refeeding on myenteric neurons of the rat large intestine: a quantitative morphological study. Cell Tissue Res. 310:1-7.

Christensen J., Stiles M.J., Rick G.A. \& Sutherland J. 1984. Comparative anatomy of the myenteric plexus of the distal colon in eight mammals. Gastroenterol. 86:706-713.

Costa F.A.A.M. \& Brookes S.J.H. 1994. The enteric nervous system. Am. J. Gastroenterol. 89:S129-S137.

Cowen T., Johnson R.J.R., Soubeyre V. \& Santer R.M. 2000. Restricted diet rescues rat enteric motor neurones from age related cell death. Gut 47:653-660.

Cracco C. \& Filogamo G. 1994. Quantitative study of the NADPHdiaphorase-positive myenteric neurons of the rat ileum. Neuroscience 61:351-359.

De Souza R.R., Carvalho C.A.F. \& Fujimura I. 1988. Plexo mioentérico do esôfago humano em preparados de membrana. Revta Hosp. Clin. Fac. Med. São Paulo 43:81-83.

Donowitz M. \& Binde H. 1979. Mechanism of fluid and electrolyte secretion in the germ-free rat cecum. Dig. Dis. Sci. 24:551-559.

Dupont J.R., Jervis H.R. \& Sprinz H. 1965. Auerbach's plexus of the rat cecum in relation to the germfree state. J. Comp. Neurol. 125:11-18.

Fregonesi C.E.P.T., Miranda-Neto M.H. \& Molinari S.L. 1998. Estudo morfológico e quantitativo dos neurônios do plexo mioentérico do corpo do estômago de Rattus norvegicus. Acta Scientiarum 20:221-224.

Furlan M.M.D.P. 2000. Ontogenia e filogenia do sistema nervoso entérico. Arq. Ciênc. Saúde Unipar 4:149-157.

Furness J.B. \& Bornstein J.C. 1995. The enteric nervous system and its extrinsic connections, p.2-24. In: Uamada T. (ed.), Textbook of Gastroenterology. Lippincott J.B., Philadelphia.

Furness J.B., Li Z.S., Young H.M. \& Förstermann U. 1994. Nitric oxide synthase in the enteric nervous system of the guinea-pig: a quantitative description. Cell Tissue. Res. 277:139-149.

Gabella G. 1969. Detection of nerve cells by a histochemical technique. Experientia 25:218-219.

Gabella G. 1971. Neuron size and number in the myenteric plexus of the newborn and adult rat. Am. J. Anat. 109:81-95.

Gabella G. 1979. Innervation of the gastrointestinal tract. Int. Rev. 59:129193.

Gabriel R., Halasy K. \& Csoknya M. 1988. Visualization of neurons by $\mathrm{NADH}$-diaphorase staining in the myenteric plexus of some invertebrate and vertebrate species. Z. Mikrosk. Anat. Forsch. 102:769-784.

Gershon M.D. 1981. The enteric nervous system. Annu. Rev. Neurosci. 4:227-272.

Gershon M.D., Kirchgessner A.L. \& Wade P.R. 1994. Functional anatomy of the enteric nervous system, p.381-422. In: Johnson L.R. (ed.), Physiology of the Gastrointestinal Tract. Raven Press, New York.

Goyal R.K. \& Hirano I. 1996. The enteric nervous system. N. Engl. J. Med. 334:1106-1115.

Hanani M. 2004. Multiple myenteric networks in the human appendix. Auton. Neurosci. 110:49-54.

Hansen M.B. 2003. Neurohumoral control of gastrointestinal motility. Physiol. Res. 52:1-30.

Hollander D. \& Truscott T.C. 1974. Colonic absorption of vitamin K-3. J. Lab. Clin. Med. 83:648-656.

Irwin D.A. 1931. The anatomy of the Auerbach's plexus. Am. J. Anat. 49:141-166.

Jarvinen M.K., Wollmann W.J., Powrozek T.A., Schultz J.A. \& Powley T.L. 1999. Nitric oxide synthase-containing neurons in the myenteric plexus of the rat gastrointestinal tract: distribution and regional density. Anat. Embryol. 199:99-112.

Miranda-Neto M.H., Molinari S.L., Natali M.R.M. \& Sant'ana D.M.G. 2001. Regional differences in the number and type of myenteric neurons of the ileum of rats: a comparison of techniques of the neuronal evidentiation. Arq. Neuro-Psiquiatr. 59:54-59.

Molinari S.L., Fernandes C.A., Oliveira L.R., Sant'ana D.M.G. \& MirandaNeto M.H. 2002. NADH-diaphorase positive myenteric neurons of the aglandular region of stomach of rats (Rattus norvergicus) subjected to desnutrition. Revta Chil. Anat. 20:19-23.

Morikawa S. \& Komuro T. 1998. Distribution of myenteric NO neurons along the guinea-pig esophagus. J. Auton. Nerv. Syst. 74:91-99.

Nichols K., Staines W. \& Krantis A. 1993. Nitric oxide synthase distribution in the rat intestine: a histochemical analysis. Gastroenterol. 105:16511661.

Oliveira L.R., Molinari S.L., Pereira M.A.S., Miranda-Neto M.H. \& Sant'ana D.M.G. 2002. Localização dos neurônios mioentéricos no estômago aglandular e glandular de ratos (Rattus norvergicus). Arq. Ciênc. Saúde Unipar 4:215-220. 
Peng X., Feng J.B., Yan H., Zhao Y. \& Wang S.L. 2001. Distribution of nitric oxide synthase in stomach myenteric plexus of rats. J. Gastroenterol. 7:852-854.

Petith M.M. \& Schedl H.P. 1976. Intestinal adaptation to dietary calcium restriction: in vivo cecal and colonic calcium transport in the rat. Gastroenterol. 71:1039-1042.

Rayssiguier Y. \& Remesy C. 1977. Magnesium absorption in the caecum of rats related to volatile fatty acids production. Ann. Rech. Vet. 8:105110.

Rerat A. 1978. Digestion and absorption of carbohydrates and nitrogenous matters in the hindgut of the omnivorous nonruminant animal. J. Anim. Sci. 46:1808-1837.

Roger T., Cabanie P. \& Ferre J.P. 1991. Microscopic and functional anatomy of the ileal papilla and caecocolonic valve in the rat. Acta Anat. 142:299-305.

Sant'ana D.M.G., Miranda-Neto M.H., De Souza R.R. \& Molinari S.L. 1997. Morphological and quantitative study of the myenteric plexus of the ascending colon of rats subjected to proteic desnutrition. Arq. Neuro-Psiquiatr. 55:687-695.

Schemann M. \& Neunlist M. 2004. The human enteric nervous system. Neurogastroenterol. Motil. 16:55-59.

Scherer-Singler U., Vincen, S.R., Kimura H. \& McGeer E.G. 1983. Demonstration of a unique population of neurons with NADPHdiaphorase histochemistry. J. Neurosci. Methods 9:229-234.

Seyfert C.E. 2003. Densidade e área do perfil celular dos neurônios mioentéricos reativos a acetilcolinesterase, NADH e NADPH-diaforase positivos do ceco de ratos (Rattus norvegicus) adultos. Dissertação de Mestrado, USP, São Paulo. 77p.

Snipes R.L. 1981. Anatomy of the cecum of the laboratory mouse and rat. Anat. Embryol. 162:455-474.

Sternini C. 1988. Structural and chemical organization of the myenteric plexus. Annu. Rev. Physiol. 50:81-93.

Timmermans J.P., Adriaensen D. \& Lefebvre R. 1999. Postnatal development of nitrergic neurons in the myenteric plexus of rat stomach. Histochem. Cell. Biol. 111:429-434

Toole L., Belai A. \& Burnstock G. 1998. A neurochemical characterisation of the golden hamster myenteric plexus. Cell Tissue. Res. 291:385394.

Wilhelm M., Bátori Z., Pásztor I. \& Gábriel R. 1998. NADPH-Diaphorase positive myenteric neurons in the ileum of guinea-pig, rat, rabbit and cat: a comparative study. Eur. J. Morphol. 36:143-152.

Wood J.D. 1994. Physiology of the enteric nervous system, p.423-482. In: Johnson L.R., Alpers D.H., Jacobson E.D. \& Walsh J.H. (ed.), Physiology of the Gastrointestinal Tract. Raven Press, New York.

Wu M., van Nassauw L., Kroese A.B.A., Adriaensen D. \& Timmermans J.P. 2003. Myenteric nitrergic neurons along the rat esophagus: evidence for regional and strain differences in age-related changes. Histochem. Cell. Biol. 119:395-403.

Young H.M., Furness J.B., Shuttleworth C.W.R., Bredt D.S. \& Snyder S.H. 1992. Co-localization of nitric oxide synthase immunoreactivity and NADPH diaphorase staining in neurons of the guinea-pig intestine. Histochemistry 97:375-378. 